\title{
Nuclear Transfer Preserves the Nuclear Genome of Freeze-Dried Mouse Cells
}

\author{
Tetsuo ONO ${ }^{1,2)}$, Eiji MIZUTANI ${ }^{1)}$, Chong $\mathrm{LI}^{1,3)}$ and Teruhiko WAKAYAMA ${ }^{1-3)}$ \\ ${ }^{1)}$ Laboratory for Genomic Reprogramming, RIKEN Center for Developmental Biology, Kobe 650-0047, ${ }^{2)}$ Department of \\ Medical Science, Graduate School of Medicine, Kyoto University, Kyoto 606-8502 and ${ }^{3)}$ Department of Bioscience, \\ Graduate School of Science and Technology, Kwansei Gakuin University, Sanda 669-1337, Japan
}

\begin{abstract}
Mouse spermatozoa can be freeze dried without losing genetic integrity and reproductive potential. However, it is not known if freeze-dried mouse cells similarly maintain their genetic integrity and developmental potential following nuclear transfer. Here, we investigated the developmental capacity and embryonic stem (ES) cell derivation of reconstructed oocytes by nuclear transfer using freeze-dried cumulus or ES cells. Cumulus and ES cells were lyophilized overnight and stored at $4 \mathrm{C}$ for up to 1 week. After rehydration, all cells showed membrane damage and were unviable. However, following nuclear transfer, 1-4\% of the reconstructed oocytes developed to the blastocyst stage. A total of five nuclear transfer ES (ntES) cell lines were generated from blastocysts and morulae. All ntES cell lines had normal karyotypes and were positive for the ES-cell-specific markers (alkaline phosphatase, Oct3/4 and Nanog). After aggregation of ntES cells with fertilized embryos, chimeric mice with a high level of coat color chimerism were generated. Our findings show that the genomic integrity of cells can be maintained after freeze-drying and that it is possible to produce offspring from the cells using nuclear transfer techniques.
\end{abstract}

Key words: Clone, Freeze-dry, Nuclear transfer, Nuclear transfer embryonic stem (ntES) cell, Mouse, Reprogramming

(J. Reprod. Dev. 54: 486-491, 2008)

$\mathbf{F}$

reeze-dried sperm can support normal development into healthy mice if injected directly into mature oocytes even though the lyophilized spermatozoa are all dead in the conventional sense $[1,2]$. It has been shown that the complete sperm DNA can be maintained after freeze-drying in several species [3, 4]. In mammals, spermatozoa are structurally compatible with lyophilisation since they are small cells with a low level of hydration and their transcriptionally inactive DNA are tightly packed with protamines [5]. In contrast to spermatozoa, it has been thought that somatic cells would be less tolerant to the freeze-drying process because they are larger, have a higher water content and their chromatin organization is unpacked, making them vulnerable to the freezedrying process. It is not known if freeze-dried cell nuclei can generate further generations following nuclear transfer.

It has been shown that when frozen cells are thawed without cryoprotection, nuclear transfer ES (ntES) cell lines can be generated from the dead cell nuclei and live mice can be created via germline transmission of chimeric mice [6]. We have already succeeded in producing live cloned mice from mouse somatic cells frozen for 16 years [7], and this suggests that the viability of donor cells is not important for producing the next generation using nuclear transfer. Recently, Loi et al. reported that sheep blastocysts could be generated from freeze-dried somatic cells with a similar success rate as for fresh cells following storage at room temperature for 3 years [8]. This was the first attempt to use freeze-dried somatic cells for nuclear transfer, but that study only demonstrated the developmental potential to the blastocyst stage rather than the preservation of nuclear function. Blastocyst development per se cannot demon-

Accepted for publication: September 16, 2008

Published online in J-STAGE: October 15, 2008

Correspondence: T Wakayama (e-mail: teru@cdb.riken.jp) strate the nuclear integrity because most oocytes fertilized with damaged or dead freeze-dried spermatozoa can develop into morphologically normal blastocysts [9].

Trehalose protects organisms against various stresses such as dehydration, freezing and osmotic pressure. Previous studies have shown that trehalose protects mammalian cells, and the presence of trehalose on both sides of the cell membrane can maximize the protective effect of trehalose during cell freezing and drying [10, 11]. Trehalose also has a protective effect on evaporatively dried mouse spermatozoa [12, 13].

We investigated the nuclear integrity of freeze-dried cells with and without trehalose. Following rehydration of dead freeze-dried cells, cloned blastocysts were obtained by nuclear transfer. We established ntES cell lines from morulae and blastocysts, and nuclear integrity was then examined by production of chimeric mice. The results indicate that freeze-drying of mouse cells as well as spermatozoa can be used to maintain the complete mouse genome for future production of offspring.

\section{Materials and Methods}

\section{Animals}

Adult female B6D2F1 mice (2-3 months old), pCX-eGFP C57BL/6 Tg females, DBA/2 males and adult ICR mice (2-6 months old) were purchased from Shizuoka Laboratory Animal Center (Hamamatsu, Japan). We then produced pCX-eGFPB6D2F1 mice by mating C57BL/6 Tg females with DBA/2 males. All animal experiments conformed to the Guide for the Care and Use of Laboratory Animals and were approved by the Institutional Committee of Laboratory Animal Experimentation of the RIKEN Kobe Institute. 
Preparation of ES or cumulus cells and freeze drying

We used an ES cell line derived from previously established GFP-129B6F1 Tg mouse lines [14]. Non-GFP ES cells (C14) [14] were used for viability testing. ES cells were detached from their dishes by treatment with $0.25 \%$ trypsin and $0.75 \mathrm{mM}$ EDTA. The cell suspension was pipetted for a few minutes to release the cells from the dish surface and centrifuged ( 300 G, 5 min). The supernatant was removed, and the cells were washed with modified EGTA solution (mEGTA: 50 mM EGTA, 100 mM Tris-HCl, pH 8.0) [15] with or without $0.5 \mathrm{M}$ trehalose. Mature pCX-eGFP-B6D2F1 mice were superovulated by administration of $5 \mathrm{IU}$ equine chorionic gonadotropin (eCG; Teikokuzoki, Tokyo, Japan) followed $48 \mathrm{~h}$ later by 5 IU human chorionic gonadotropin (hCG, Teikokuzoki). Cumulus-oocyte complexes were collected from the oviducts about $16 \mathrm{~h}$ after injection of hCG. After collection, cumulus cells were dispersed with $0.1 \%$ bovine testicular hyaluronidase (Sigma-Aldrich, St. Louis, MO, USA) in droplets of HEPES-buffered CZB medium (HEPES-CZB). After several minutes, the cumulus cells were transferred to 1.5-ml tubes and centrifuged (300 G, $5 \mathrm{~min}$ ). The supernatant was removed, and the cells were washed with mEGTA solution with or without $0.5 \mathrm{M}$ trehalose. Ten to $50 \mu \mathrm{l}$ of each cell suspension prepared as above was put in 1.5-ml tubes (overnight) or vials (one-week storage). Each tube was put in a freezer at $-30 \mathrm{C}$ and kept there for $3 \mathrm{~h}$ before connection to the lyophilizer. After drying in a vacuum for more than $5 \mathrm{~h}$, each vial was stored at $4 \mathrm{C}$ for 6 days.

\section{Viability of cells}

The viability of lyophilized cells was examined using a LIVE/ DEAD Reduced Biohazard Viability/Cytotoxicity kit (Molecular Probes $^{\mathrm{TM}}$; Invitrogen, Carlsbad, CA, USA) according to the manufacturer's protocols. SYTO 10, a green fluorescent nucleic acid stain, is a highly membrane-permeant dye that labels all cells, including those with intact plasma membranes. DEAD Red ${ }^{\mathrm{TM}}$ (ethidium homodimer-2) is a cell-impermeant red fluorescent nucleic acid stain that labels only cells with compromised membranes. In this experiment, non-GFP ES cells (C14) were used, and the experiment was repeated three times to obtain more than 1,000 cells. We also examined the viability of rehydrated cells by culturing them in ES cell medium and investigated cell attachment and growth in culture dishes.

\section{Nuclear transfer and ntES cell establishment}

Oocyte collection and nuclear transfer were performed as previously described $[16,17]$ with slight modifications. The donor cells were suspended in 1\% PVA-NIM or 4\% PVP-NIM solution [18, 19] instead of $10 \%$ PVP-HEPES HTF solution (Irvine Scientific, Santa Ana, CA, USA). The oocytes reconstructed with cumulus cells were activated [20] with $5 \mathrm{nM}$ TSA at $37^{\circ} \mathrm{C}$ under $5 \% \mathrm{CO}_{2}$ in air for $6 \mathrm{~h}[21,22]$, and then the oocytes were cultured in CZB medium containing $5 \mathrm{nM}$ trichostatin A (TSA) for $3 \mathrm{~h}$. After TSA treatment, cloned embryos were transferred to CZB medium and cultured for up to 4 days. If ES donor cells were used, the reconstructed oocytes were activated without using TSA because TSA only improves the cloning success rate of somatic donor cells [21].

After the cloned embryos developed to the morula or blastocyst stage, they were used to establish ntES cell lines as previously described [14, 23] except that 20\% knockout serum replacement and $0.1 \mathrm{mg} / \mathrm{ml}$ adrenocorticotropic hormone (American Peptide Company, Sunnyvale, CA, USA) were added to the ES cell medium instead of fetal calf serum [24].

\section{Production of chimeric mice}

For production of diploid chimeric mice, ntES cells were introduced into the perivitelline spaces of fertilized 4-8-cell stage embryos collected from ICR strain mice using a piezo-actuated microinjection pipette. Following incubation of these aggregates in CZB medium for $24 \mathrm{~h}$ and development to the morula or blastocyst stage, embryos were transferred to a pseudopregnant ICR female ( $2.5 \mathrm{dpc}$ ) and examined at $9.5 \mathrm{dpc}$ or $19.5 \mathrm{dpc}$ through natural birth or Caesarian section. At birth, the GFP expression was noted, and at adulthood, black eyes and chimeric contribution to more than half the coat color was considered to indicate "high" chimerism.

\section{Immunofluorescence staining, alkaline phosphatase staining and karyotype analysis by Giemsa}

Established ES cell lines were tested for pluripotency by alkaline phosphatase staining, according to the manufacturer's protocol (Sigma-Aldrich). To test the normality of established ntES cell lines, the expression levels of Oct3/4 and Nanog were examined using immunofluorescence staining. Initially, ntES cell lines were cultured for 2 days on gelatin-coated 8-well chamber slides (Nalge Nunc International, Rochester, NY, USA). After removing the culture medium, the slides were air dried for 15 min and fixed in $4 \%$ paraformaldehyde for $20 \mathrm{~min}$. The fixed cells were then washed twice in phosphate buffered saline (PBS, Sigma-Aldrich), stored overnight in PBS with $1 \%$ bovine serum and $0.1 \%(\mathrm{v} / \mathrm{v})$ Triton $\mathrm{X}$ 100 at $4 \mathrm{C}$ and incubated with antibodies at room temperature. The primary antibodies used were mouse monoclonal anti-Oct3/4 (Santa Cruz Biotechnology, Santa Cruz, CA, USA) or rabbit polyclonal anti-Nanog (ReproCELL, Tokyo, Japan). After being washed three times in PBS, the cells were incubated with the following secondary antibodies: Alexa Fluor 568-labeled goat antimouse IgG and Alexa Fluor 568-labeled goat antirabbit IgG (both from Molecular Probes ${ }^{\mathrm{TM}}$ ). After three washes in PBS, the chromosomes were stained with 4,6-diamidino-2-phenylindole (DAPI; $2 \mu \mathrm{g} / \mathrm{ml}$ : Molecular Probes ${ }^{\mathrm{TM}}$ ). Following complete washing, the cells were coverslipped with Vectashield mounting medium (Vector Laboratories, Burlingame, CA, USA).

Chromosomes from the ntES cells were stained using Giemsa as previously described [14, 23, 25].

\section{Statistically analysis}

Outcomes were evaluated using $\chi$-square tests, and $\mathrm{P}<0.01$ was assumed to be statistically significant.

\section{Results and Discussion}

We previously showed that mouse spermatozoa can be freezedried without loss of genetic integrity and reproductive potential and that reconstituted lyophilized sperm can support normal development when injected into mature oocytes [1]. Here, we 


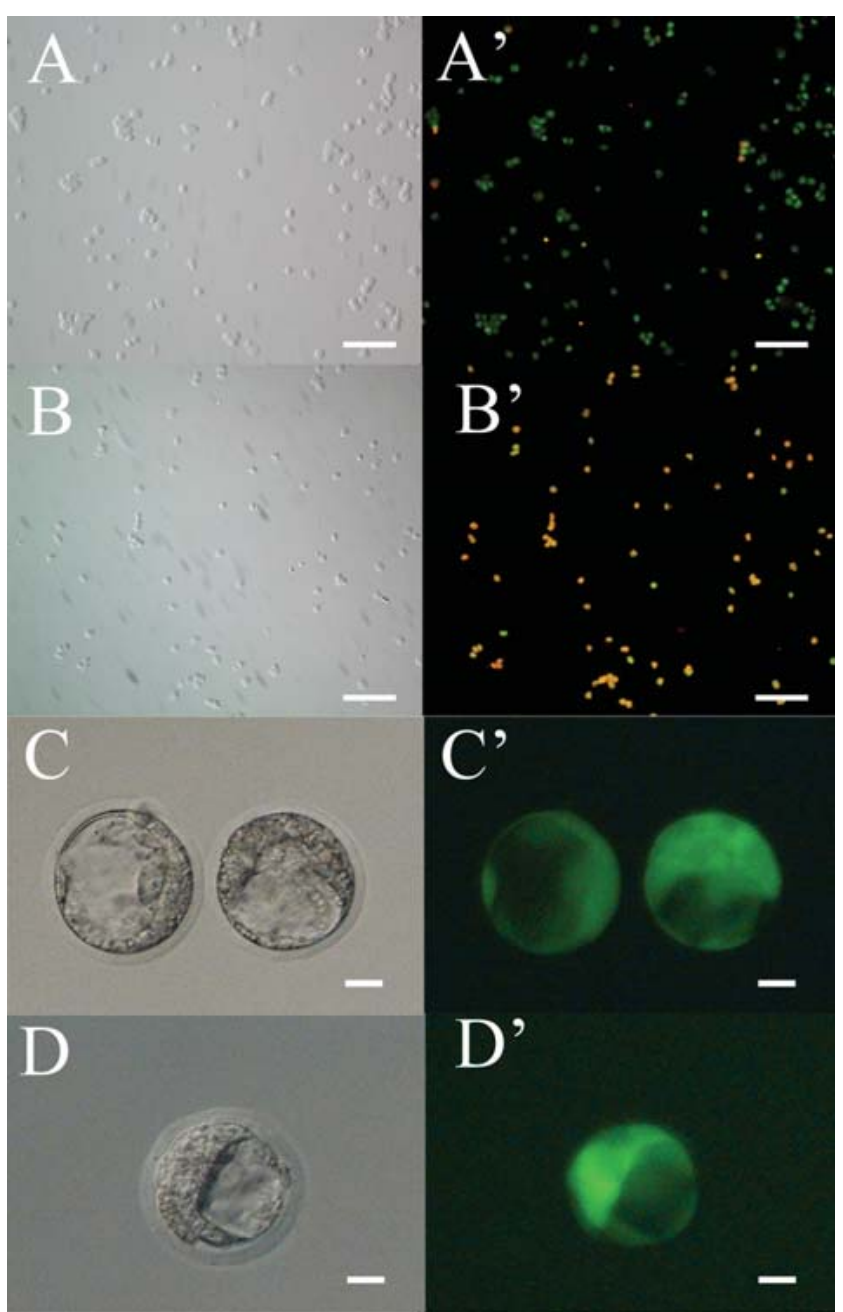

Fig. 1. Freeze-dried cells and cloned blastocysts. A-A': LIVE/DEAD staining of fresh ES cells. A: Bright field. A': Merge image. Fresh cells exhibit green staining but no red staining, indicating that the cells were live. B-B': LIVE/DEAD staining of freezedried ES cells. B: Bright field. B': Merge image. All ES cells exhibit green and red staining, indicating that the cells were dead following freeze-drying. C-C': Expression of GFP in a cloned blastocyst derived from freeze-dried ES cells. C: Bright field. C': GFP expression. D-D': Expression of GFP in a cloned blastocyst derived from freeze-dried cumulus cells. D: Bright field. D': GFP expression. Scale bars: A-B'=100 $\mu \mathrm{m}, \mathrm{C}-\mathrm{D}^{\prime}=20 \mu \mathrm{m}$.

investigate the nuclear integrity of freeze-dried mouse cells by generating cloned embryos, ntES cell derivation and production of chimeric mice.

Mouse cumulus and ES cells were lyophilized according to the protocol described in our previous report [1]. After rehydration, the viability of more than 1,000 freeze-dried cells was determined using LIVE/DEAD staining. Ninety-three percent of fresh cells were live, whereas all rehydrated cells (100\%) were judged to be dead based on membrane impermeable staining (Fig. 1A-B'). We also checked if any cells survived after freeze-drying and rehydration by culturing them in culture media, but none attached to the

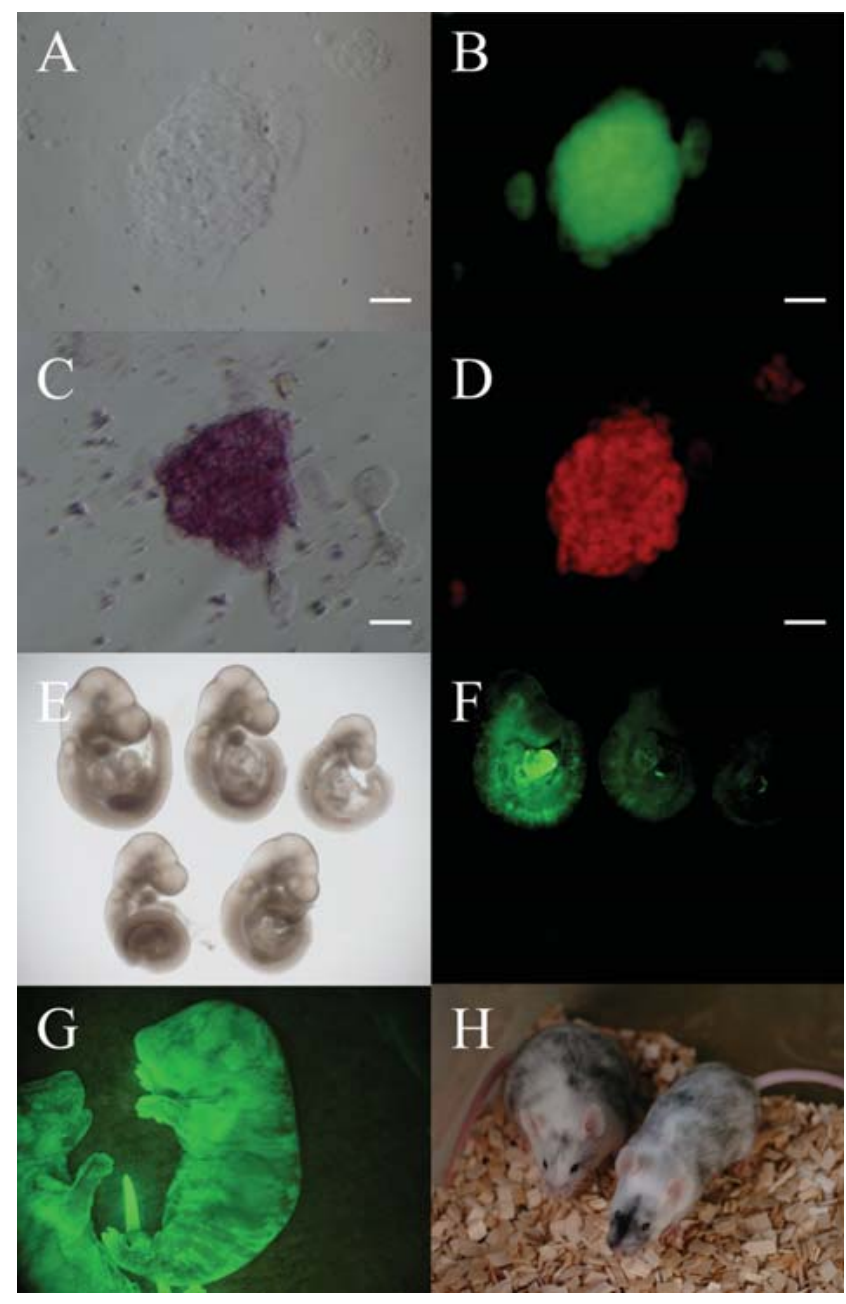

Fig. 2. Generation of ntES cell and chimeric mice. A-D: ntES cell line derived from freeze-dried ES cells. A: Bright field. B: GFP expression. C: Alkaline phosphatase staining. D: Immunofluorescent staining for Oct3/4. E-F: Chimeric mice $(9.5$ dpc) were produced by injecting ntES cells derived from freezedried somatic cell nuclei. E: Bright field. F: GFP expression. G$\mathrm{H}$ : Chimeric mice were produced by injecting ntES cells derived from freeze-dried ES cell nuclei. Scale bars $=40 \mu \mathrm{m}$.

dish or grew, irrespective of the cell type (data not shown). These results show that cells do not survive after freeze-drying and rehydration. When these dead cells were placed in 10\% PVP-HEPES HTF solution as for live cell nuclear transfer [16], they were shrunken and hard, probably because of cell membrane damage (data not shown). To overcome this problem, we modified the nuclear transfer method by using 1\% PVA-NIM or 4\% PVP-NIM solution instead of the 10\% PVP-HEPES HTF solution. This did not result in any morphological changes in the donor cells.

Using this modified method, we injected rehydrated freeze-dried donor cells into enucleated oocytes and attempted to establish ntES cell lines when the cloned embryos developed to morulae or blastocysts. We did not try to produce cloned mice by embryo transfer into recipient females because the generation rate of ntES cell lines 
Table 1. Preimplantation development of reconstructed oocytes after nuclear transfer using freeze-dried cells

\begin{tabular}{|c|c|c|c|c|c|c|c|c|c|}
\hline \multirow{3}{*}{$\begin{array}{l}\text { Storage } \\
\text { period }\end{array}$} & \multirow{3}{*}{$\begin{array}{l}\text { Cell type } \\
\text { (strain) }\end{array}$} & \multirow{3}{*}{ Trehalose } & \multirow{3}{*}{$\begin{array}{c}\text { No. } \\
\text { enucleated } \\
\text { oocyte }\end{array}$} & \multirow{3}{*}{$\begin{array}{c}\text { No. } \\
\text { surviving } \\
\text { after NT } \\
(\%)\end{array}$} & \multirow{3}{*}{$\begin{array}{l}\text { No. } \\
\text { pronuclear } \\
\text { formation } \\
\text { (\%) }\end{array}$} & \multicolumn{4}{|c|}{ No. (\%) embryo developed ${ }^{* 1}$} \\
\hline & & & & & & $24 \mathrm{~h}$ & $48 \mathrm{~h}$ & $72 \mathrm{~h}$ & $96 \mathrm{~h}$ \\
\hline & & & & & & 2-cell & 4-8-cell & $\begin{array}{l}\text { Morulāa } \\
\text { Blastocyst }\end{array}$ & Blastocyst \\
\hline \multirow[t]{2}{*}{ Fresh $^{* 2}$} & $\begin{array}{l}\mathrm{ES} \\
\text { (B6D2F1) }\end{array}$ & - & 193 & - & 108 & - & - & $20(19)$ & - \\
\hline & $\begin{array}{l}\text { Somatic } \\
\text { (B6D2F1) }\end{array}$ & - & 198 & - & 153 & - & - & $107(70)$ & - \\
\hline \multirow[t]{4}{*}{ Over-night } & ES & - & 376 & $207(55)$ & 192 (93) & $62(32)^{\mathrm{a}}$ & $4(2)$ & $2(1)$ & $2(1)$ \\
\hline & (129B6F1) & + & 315 & $141(45)$ & 132 (94) & $54(41)^{\mathrm{a}}$ & $11(8)$ & $5(4)$ & $5(4)$ \\
\hline & Śomatic & - & $16 \overline{8}$ & $99^{-}(59)$ & $\overline{84}(\overline{8} 5 \overline{)}$ & $\overline{71}(8 \overline{5})^{\mathrm{b}}$ & $\overline{1} 1 \overline{1}(1 \overline{3})^{-}$ & $\overline{8}(10)^{-}$ & $1(1)$ \\
\hline & $(\mathrm{B} 6 \mathrm{D} 2 \mathrm{~F} 1)$ & + & 186 & $101(54)$ & $92(91)$ & $69(75)^{\mathrm{b}}$ & $13(14)$ & $7(8)$ & $1(1)$ \\
\hline \multirow[t]{2}{*}{1 week } & ES & - & 161 & $93(58)$ & 88 (95) & $22(25)^{\mathrm{a}}$ & $2(2)$ & $2(2)$ & $2(2)$ \\
\hline & $(129 B 6 F 1)$ & + & 163 & $99(61)$ & $97(98)$ & $34(35)^{\mathrm{a}}$ & $1(1)$ & $1(1)$ & $1(1)$ \\
\hline
\end{tabular}

${ }^{{ }^{*}}$ : Percentage based on the number of pronuclear embryos. ${ }^{* 2}$ : These data are from reference \#28. Values with different superscripts in the same column are siginificantly different $(\mathrm{P}<0.01)$.

Table 2. Establishment of ntES cell lines from freeze-dried cells

\begin{tabular}{llccccc}
\hline $\begin{array}{l}\text { Storage } \\
\text { period }\end{array}$ & $\begin{array}{l}\text { Cell type } \\
\text { (strain) }\end{array}$ & Trehalose & $\begin{array}{c}\text { No. of enucleated } \\
\text { oocyte }\end{array}$ & $\begin{array}{c}\text { No. of cloned morulae } \\
\text { or blastocysts used }\end{array}$ & $\begin{array}{c}\text { No. of established } \\
\text { ntES cell lines (\%) }\end{array}$ & $\begin{array}{c}\text { Name of } \\
\text { cell line }\end{array}$ \\
\hline Fresh $^{* 2}$ & $\begin{array}{l}\text { ES } \\
\text { (B6D2F1) }\end{array}$ & - & 193 & 20 & $6(30)$ & - \\
& Somatic & - & 198 & 107 & $22(21)$ & - \\
\hline Over-night & ES & - & 376 & 2 & 0 & - \\
& $(129 B 6 F 1)$ & + & 315 & 9 & $2(22)$ & E1D1, 2 \\
\hline 1 week & ES & - & 168 & 5 & $2(50)$ & - \\
& $($ B6D2F1) & + & 186 & 4 & $1(100)$ & S1D1, 2 \\
\hline
\end{tabular}

${ }^{* 1}$ Percentage based on the number of cloned morulae or blastocysts used. ${ }^{* 2}$ These data are from reference \#28.

is higher than the rate of cloned mice production $[14,16,23,26$, 27]. Approximately $90 \%$ of the oocytes formed pronuclei following nuclear transfer, irrespective of donor cell type and storage period (Table 1). After culturing the nuclear transfer embryos, 70$80 \%$ of the embryos derived from freeze-dried cumulus cells developed to the two-cell stage at $24 \mathrm{~h}$. This percentage was significantly higher than the production of embryos from freezedried ES cells (30-40\%, $\mathrm{P}<0.01$ ). When embryos were cultured for up to $96 \mathrm{~h}$, at least one embryo (1-4\%) reached the blastocyst stage in all groups, irrespective of donor cell type or preservation period (Table 1). The morula or blastocyst stage embryos were then used to generate ntES cell lines, and we were able to successfully obtain five ntES cell lines from these embryos (Table 2). All morula, blastocyst and established ntES cell lines expressed GFP genes, indicating that the nuclei of reconstructed oocytes originated from the donor cells (Fig. 1C-D', 2B).

We used trehalose in some experiments during freeze-drying of donor cells. Trehalose is found in the cells of many organisms that naturally survive dehydration, a phenomenon known as anhydrobiosis. The mechanism by which trehalose confers tolerance to desiccation is unclear, although trehalose is thought to replace the shell of water from the surfaces of macromolecules. However, all our cells were dead after rehydration even with trehalose treatment, and the rate of development from the oocyte to blastocyst stage was the same with or without trehalose (Table 1). These results suggest trehalose did not improve the survival rate of the freeze-dried mouse cells. Once the cells were dead, later developmental viability depended on nuclear integrity, which is affected by factors other than protection by trehalose.

The newly established ntES cells were analyzed for pluripotency by alkaline phosphatase and immunofluorescence staining for Oct3/4 and Nanog, and their in vitro differentiation potential was assessed by embryoid body formation. All ntES cell lines stained positive for the ES-cell-specific markers (Fig. 2A-D, Nanog is not shown) and formed embryoid bodies in a pattern similar to that observed in normally fertilized ES cells (data not shown). In addi- 
Table 3. Contribution of ntES cells in chimeric mice

\begin{tabular}{|c|c|c|c|c|c|c|c|}
\hline \multicolumn{5}{|c|}{ Origin of ntES cell line } & \multirow{2}{*}{$\begin{array}{l}\text { No. of used } \\
\text { embryos } \\
\text { (recipients) }\end{array}$} & \multicolumn{2}{|c|}{ No. of offspring } \\
\hline Line ID & $\begin{array}{l}\text { Mouse } \\
\text { strain }\end{array}$ & Donor cell & $\begin{array}{l}\text { Storage } \\
\text { period }\end{array}$ & $\begin{array}{c}\text { Normal } \\
\text { karyotype \% }\end{array}$ & & Total $^{* 1}$ & High $(>50 \%)^{* 2}$ \\
\hline E1D1 & 129B6F1 & ES & 1 day & $19 \%$ & $192(13)$ & 19 & 7 \\
\hline E1D2 & 129B6F1 & ES & 1 day & $72 \%$ & $143(11)$ & 31 & 7 \\
\hline E1W1 & 129B6F1 & ES & 1 week & $80 \%$ & $74(6)$ & 9 & 3 \\
\hline S1D1 & B6D2F1 & Somatic & 1 day & $82 \%$ & $157(11)$ & 31 & 4 \\
\hline S1D2 & B6D2F1 & Somatic & 1 day & $60 \%$ & $144(10)$ & 22 & 4 \\
\hline
\end{tabular}

${ }^{*}$ Some pups died soon after birth. ${ }^{* 2}$ The contribution of ntES cells to each chimera was scored as high (> 50\% of the coat color or GFP expression was derived from ntES cells).

tion, chromosome analysis revealed that all ntES cell lines had the normal range of karyotypes. To determine the possible pluripotency of these ntES cells, chimeric mice were produced by injecting the ntES cells into the perivitelline spaces of 4-8-cell stage embryos derived from the ICR albino mouse strain. These embryos were then transferred into pseudopregnant recipients. The chimerism or ntES cell contribution rate was identified by the presence of black eyes, coat color and GFP expression. As shown in Table 3 and Fig. 2, chimeric mice (with more than half the target coat color) were obtained from all cell lines. These results suggest ntES cell lines derived from freeze-dried cells are pluripotent and have the potential to generate the next generation via germ cells in chimeric mice.

The developmental rate to morula or blastocyst stage was extremely low compared with our previous results using fresh cells as donors (20-70\% vs. 1-10\%) [16, 23, 27, 28]. Possible explanations for this low success rate include the possibility that 1 ) nonviable cells lose nuclear integrity within a short time or 2) the freeze-drying process damages donor nuclei. It has been shown that even dead cells after freeze-thawing can generate ntES cell lines within the normal range [6]. This indicates that the freezedrying process is the more likely cause of the low success rate. However, Loi et al. reported that blastocysts could be produced from freeze-dried sheep somatic cells with a success rate equivalent to that for fresh cells [8]. Even after storage for 3 years at room temperature, freeze-dried somatic cells still had the developmental potential for blastocyst formation following nuclear transfer. Their study suggests that the freeze-drying process does not prevent the development of donor cells after nuclear transfer. Although the mouse is the first species in which offspring from freeze-dried spermatozoa were produced with a high success rate, mouse cells may be less tolerant to freeze-drying than other species.

Although the establish rate was low, we were able to generate several ntES cell lines that differentiated into the organs in chimeric mice. This is strong evidence for the nuclear integrity of freeze-dried cells. If donor nuclei had sustaine damage during freeze-drying, it appears that minor damage can be repaired during the course of ES cell generation [29]. Loi et al. only demonstrated developmental potential to the blastocyst stage and did not show nuclear integrity because most oocytes fertilized with damaged freeze-dried spermatozoa developed into morphologically normal blastocysts [9]. We have demonstrated, for the first time, that the complete nuclear genome can be preserved after freeze-drying and that chimeric mice can be produced from these cell nuclei using ntES cell technology.

In conclusion, we have demonstrated successful reprogramming of nuclei from freeze-dried cells in mice. Genomic integrity can be maintained in the freeze-dried condition, and chimeras can be produced from ntES cells. In this study, although we did not try to produce cloned mice using freeze-dried cells because the generation rate of cloned mice is low, it is likely that tetraploid chimera or cloned mice can be produced using these ntES cell lines.

\section{Acknowledgments}

We thank H Ohta, K Yamagata, S Wakayama, T Oyanagi and Y Sakaide for preparing this manuscript. We are grateful to the Laboratory for Animal Resources and Genetic Engineering of RIKEN Kobe Center for housing the mice. Financial support for this research was provided by Grants-in-Aid for Young Scientists B (19780213, to E.M.) and Scientific Research in Priority Areas (15080211, to T.W.) and by the Project for the Realization of Regenerative Medicine (to T.W.).

\section{References}

1. Wakayama T, Yanagimachi R. Development of normal mice from oocytes injected with freeze-dried spermatozoa. Nat Biotechnol 1998; 16: 639-641.

2. Kawase $\mathbf{Y}$, Tachibe $\mathbf{T}$, Jishage $K$, Suzuki $\mathbf{H}$. Transportation of freeze-dried mouse spermatozoa under different preservation conditions. J Reprod Dev 2007; 53: 1169 1174 .

3. Keskintepe L, Pacholczyk G, Machnicka A, Norris K, Curuk MA, Khan I, Brackett BG. Bovine blastocyst development from oocytes injected with freeze-dried spermatozoa. Biol Reprod 2002; 67: 409-415.

4. Liu JL, Kusakabe H, Chang CC, Suzuki H, Schmidt DW, Julian M, Pfeffer R, Bormann CL, Tian XC, Yanagimachi R, Yang X. Freeze-dried sperm fertilization leads to full-term development in rabbits. Biol Reprod 2004; 70: 1776-1781.

5. Ward WS, Zalensky AO. The unique, complex organization of the transcriptionally silent sperm chromatin. Crit Rev Eukaryot Gene Expr 1996; 6: 139-147.

6. Li J, Mombaerts P. Nuclear transfer-mediated rescue of the nuclear genome of nonviable mouse cells frozen without cryoprotectant. Biol Reprod 2008; 79: 588-593.

7. Wakayama S, Ohta H, Hikichi T, Mizutani E, Iwaki T, Kanagawa O, Wakayama T. Production of healthy cloned mice from bodies frozen at $-20{ }^{\circ} \mathrm{C}$ for 16 years. Proc Natl Acad Sci USA 2008; 105: 17318-17322.

8. Loi P, Matsukawa K, Ptak G, Clinton M, Fulka J, Jr., Nathan Y, Arav A. Freeze-dried somatic cells direct embryonic development after nuclear transfer. PLOS ONE 2008; 3 : e2978.

9. Ward MA, Kaneko T, Kusakabe H, Biggers JD, Whittingham DG, Yanagimachi R Long-term preservation of mouse spermatozoa after freeze-drying and freezing with- 
out cryoprotection. Biol Reprod 2003; 69: 2100-2108.

10. Chen T, Acker JP, Eroglu A, Cheley S, Bayley H, Fowler A, Toner M. Beneficial effect of intracellular trehalose on the membrane integrity of dried mammalian cells. Cryobiology 2001; 43: 168-181.

11. Buchanan S, Menze M, Hand S, Pyatt D, Carpenter J. Cryopreservation of human hematopoietic stem and progenitor cells loaded with trehalose: transient permeabilization via the adenosine triphosphate-dependent P2Z receptor channel. Cell Preserv Technol 2005; 3: 212-222.

12. Li MW, Biggers JD, Elmoazzen HY, Toner M, McGinnis L, Lloyd KC. Long-term storage of mouse spermatozoa after evaporative drying. Reproduction 2007; 133: 919929.

13. McGinnis LK, Zhu L, Lawitts JA, Bhowmick S, Toner M, Biggers JD. Mouse sperm desiccated and stored in trehalose medium without freezing. Biol Reprod 2005; 73: 627633.

14. Wakayama T, Tabar V, Rodriguez I, Perry AC, Studer L, Mombaerts P. Differentiation of embryonic stem cell lines generated from adult somatic cells by nuclear transfer. Science 2001; 292: 740-743.

15. Kusakabe H, Yanagimachi R, Kamiguchi Y. Mouse and human spermatozoa can be freeze-dried without damaging their chromosomes. Hum Reprod 2008; 23: 233-239.

16. Wakayama T, Perry AC, Zuccotti M, Johnson KR, Yanagimachi R. Full-term development of mice from enucleated oocytes injected with cumulus cell nuclei. Nature 1998; 394: 369-374

17. Kishigami S, Wakayama S, Thuan NV, Ohta H, Mizutani E, Hikichi T, Bui HT, Balbach S, Ogura A, Boiani M, Wakayama T. Production of cloned mice by somatic cell nuclear transfer. Nat Protoc 2006; 1: 125-138.

18. Ohta $\mathbf{H}$, Sakaide $\mathbf{Y}$, Wakayama $\mathbf{T}$. Long-term preservation of mouse spermatozoa as frozen testicular sections. J Reprod Dev 2008; 54: 295-298.

19. Kuretake S, Kimura Y, Hoshi K, Yanagimachi R. Fertilization and development of mouse oocytes injected with isolated sperm heads. Biol Reprod 1996; 55: 789-795.

20. Kishigami S, Wakayama T. Efficient strontium-induced activation of mouse oocytes in standard culture media by chelating calcium. J Reprod Dev 2007; 53: 1207-1215.
21. Kishigami S, Mizutani E, Ohta H, Hikichi T, Thuan NV, Wakayama S, Bui HT, Wakayama T. Significant improvement of mouse cloning technique by treatment with trichostatin A after somatic nuclear transfer. Biochem Biophys Res Commun 2006; 340: 183-189.

22. Kishigami S, Bui HT, Wakayama S, Tokunaga K, Van Thuan N, Hikichi $T$, Mizutani E, Ohta H, Suetsugu R, Sata T, Wakayama T. Successful mouse cloning of an outbred strain by trichostatin A treatment after somatic nuclear transfer. J Reprod Dev 2007; 53: 165-170.

23. Wakayama S, Ohta H, Kishigami S, Thuan NV, Hikichi T, Mizutani E, Miyake M, Wakayama T. Establishment of male and female nuclear transfer embryonic stem cel lines from different mouse strains and tissues. Biol Reprod 2005; 72: 932-936.

24. Ogawa K, Matsui H, Ohtsuka S, Niwa H. A novel mechanism for regulating clona propagation of mouse ES cells. Genes Cells 2004; 9: 471-477.

25. Zhao ZJ, Ouyang YC, Nan CL, Lei ZL, Song XF, Sun QY, Chen DY. Rabbit oocyte cytoplasm supports development of nuclear transfer embryos derived from the somatic cells of the camel and Tibetan antelope. J Reprod Dev 2006; 52: 449-459.

26. Wakayama S, Kishigami S, Van Thuan N, Ohta H, Hikichi T, Mizutani E, Yanagimachi R, Wakayama T. Propagation of an infertile hermaphrodite mouse lacking germ cells by using nuclear transfer and embryonic stem cell technology. Proc Nat Acad Sci USA 2005; 102: 29-33.

27. Wakayama S, Mizutani E, Kishigami S, Thuan NV, Ohta H, Hikichi T, Bui HT Miyake M, Wakayama T. Mice cloned by nuclear transfer from somatic and ntES cells derived from the same individuals. J Reprod Dev 2005; 51: 765-772.

28. Wakayama S, Jakt ML, Suzuki M, Araki R, Hikichi T, Kishigami S, Ohta H, Van Thuan N, Mizutani E, Sakaide Y, Senda S, Tanaka S, Okada M, Miyake M, Abe M, Nishikawa S, Shiota K, Wakayama T. Equivalency of nuclear transfer-derived embryonic stem cells to those derived from fertilized mouse blastocysts. Stem Cells 2006; 24: 2023-2033.

29. Wakayama T. Production of cloned mice and ES cells from adult somatic cells by nuclear transfer: how to improve cloning efficiency? J Reprod Dev 2007; 53: 13-26. 